\title{
Enhanced Adsorption of Aromatic Hydrocarbon-contaminated Aquifer Using Granular Nano Zero-valent Iron
}

\author{
D. Yousefi Kebria*, S. Mokhtarpour
}

Department of Environmental Engineering, Civil Engineering Faculty, Babol Noshirvani University of Technology, Babol, Iran

\section{PAPERINFO}

\section{Paperhistory:}

Received 25 May 2021

Accepted in revised form 12 June 2021

\section{Keywords:}

Adsorbent

Aromatic hydrocarbons

Granules of nZVI

Nano zero valent iron

Phenol

Removal

\author{
$A B S T R A C A$
}

Aromatic hydrocarbons are toxic pollutants that enter into environment through various industries. These pollutants are carcinogenic and cause genetic mutations. There are various solutions, including biological methods, extraction, and electrocoagulation. This research aims to synthesize the nano zero-valent iron (nZVI) from the ferrous waste and granules of nZVI by the chemical combination of nZVI with polyvinyl alcohol (PVA). The performance of these two adsorbents was evaluated to degradation of phenol from an aqueous solution. The physical properties of the synthesized nanoparticles were determined using SEM analysis. Effect of pH, contact time, contaminant concentration, and adsorbent dosage on the removal efficiency were studied. The results showed that the maximum removal efficiency of phenol by nZVI and GnZVI was $78,57.83 \%$, respectively, at the condition of $\mathrm{pH} 3,60$ minutes initial concentration of $8 \mathrm{ppm}$ and adsorbent dosage of $2.5 \mathrm{~g}$. The removal efficiency of phenol in acidic conditions and laboratory temperature by adsorption of nZVI is higher than GnZVI with a difference in removal efficiency of approximately $20 \%$. Equilibrium isotherms were analyzed by Langmuir and Freundlich equations and it was observed that these experiments followed Freundlich model.

\section{INTRODUCTION}

Cyclic hydrocarbons are organic compounds composed of carbon and hydrogen atoms that form rings or cyclic structures by bonding together. The simplest and first known hydrocarbon is benzene, which is highly toxic and carcinogenic. Its derivatives include phenol, which is typically soluble in aqueous media due to its use in industry. Pollution of water resources with phenol can endanger the health of humans and living organisms and pose a worrying health threat $[1,2]$. There are several methods for removing phenol, such as electrocoagulation $[3,4]$ biological methods [5, 6], extraction [7], electroFenton method [8], evaporation [9, 10], precipitation [11]. one of these methods is adsorption, which uses different adsorbents. For example, in Equation (1), zerovalent iron reacts with the pollutant as an electron donor, causing a pollutant such as phenol to be reduced by receiving electrons in the form of Equation (2).

$$
F e^{o} \rightarrow \mathrm{Fe}^{2+}+2 e^{-}
$$

Contaminant $+\mathrm{ne}^{-} \rightarrow$ Reduced contaminat

Since the preparation of the adsorbent requires a high cost of raw materials, waste that is made of this adsorbent can be used. For example, activated carbon was used to remove contaminants and it was shown that the amount of phenol adsorption depends on the surface chemistry of the adsorbents and their porosity [12]. Another study using adsorbents of almond peel and walnut charcoal reached to 91.36 and $79.17 \%$, respectively. The removal efficiency for phenol in contaminated industrial wastewater for the natural asorbrnts of almond peel and walnut charcoal were 85.54 and $65.49 \%$, respectively [13]. Another study in 2013 showed that adsorbents such as chemical olive stones of activated carbon also have a good ability to remove phenol [14]. Other adsorbents include chitosan beads [15], peat, fly ash, and bentonite $[16,17]$, wheat husk [18], and sawdust [19].

*Corresponding Author Email: dy.kebria@nit.ac.ir(D. Yousefi Kebria)

Please cite this article as: D. Yousefi Kebria, S. Mokhtarpour, 2021. Enhanced Adsorption of Aromatic Hydrocarbon-contaminated Aquifer Using Granular Nano Zero-valent Iron, Iranian (Iranica) Journal of Energy and Environment, 12(2), pp.143-148. Doi: 10.5829/ijee.2021.12.02.06 
In this study, the synthesis of the nano zero-valent iron (nZVI) and granular nano zero-valent iron (GnZVI) from the iron waste of the steel plant and the performance of two adsorbents on the degradation of phenol as an aromatic hydrocarbon from the aqueous medium were investigated. The effect of several parameters such as; $\mathrm{pH}$, contact times, contaminant concentrations, and adsorbent dosages on the removal efficiency of phenol was evaluated. The SEM test was used to observe the size of nZVI.

\section{MATERIAL AND METHODS}

\section{Materials}

All chemicals were purchased from the German company Merck and ferrous waste was collected from the steel plant. Also, phenol as an aromatic hydrocarbon with a density of $1.07 \mathrm{~g} / \mathrm{cm}^{3}$ is a colorless and moist crystalline solid that was prepared as a pollutant. The sodium borohydride (0.16 M), polyvinyl alcohol (PVA), paraffin, and sulfuric acid were used in the synthesis and granulation of nZVI. Ultrasonic bath, centrifuge, and vacuum pump were used, too.

\section{Methods}

To prepare nZVI from ferrous waste, the liquid-phase reduction method was used for synthesis, which is a chemical method using sodium borohydride as a reducing agent $[20,21]$. After the synthes is of nZVI, and SEM test was performed on it. The synthesis of nZVI, a granular adsorbent was made using a polymer called polyvinyl alcohol. Thus, $3 \mathrm{~g}$ of $\mathrm{nZVI}$ adsorbent with $5 \mathrm{~g}$ of polymer, $2 \mathrm{~mL}$ of sulfuric acid, and $30 \mathrm{~mL}$ of paraffin was converted to GnZVI after 72 hours [22, 23].

After preparing the adsorbents using two Erlenmey er under constant laboratory conditions, $20 \mathrm{mg} / \mathrm{L}$ phenol was exposed to $2.5 \mathrm{~g}$ of the adsorbent for 60 minutes at an acidic $\mathrm{pH}$ of 3 . Phenol concentration was measured by a spectrophotometer at wavelength of $500 \mathrm{~nm}$.

To explain the equilibrium state of the adsorbed component between the solid and liquid phases, the experimental adsorption equilibrium data were studied by Freundlich is otherm models in Equations (3) and (4) and Langmuir in Equations (5) and (6).

$$
\begin{aligned}
& q_{e}=K_{f} \cdot C_{e}^{(1 / n)} \\
& \ln q_{e}=1 / n \ln C_{e}+\ln K_{f} \\
& q_{e}=\frac{\mathrm{q}_{\mathrm{m}} \mathrm{K}_{\mathrm{L}} \mathrm{C}_{\mathrm{e}}}{1+\mathrm{K}_{\mathrm{L}} \mathrm{C}_{\mathrm{e}}} \\
& \frac{\mathrm{C}_{\mathrm{e}}}{q_{e}}=\frac{\mathrm{C}_{\mathrm{e}}}{\mathrm{q}_{\mathrm{m}}}+\frac{1}{\mathrm{q}_{\mathrm{m}} \mathrm{K}_{\mathrm{L}}}
\end{aligned}
$$

where $\mathrm{n}$ and $\mathrm{K}_{\mathrm{f}}$ are dimensionless constants that are related to adsorption capacity and surface adsorption intensity, respectively. Freundlich parameters are calculated using the slope of the line and the width of the origin from the equation of line $\log \mathrm{q}_{\mathrm{e}}$ versus $\log \mathrm{C}_{\mathrm{e}} . \mathrm{q}_{\mathrm{e}}$ is also the amount of adsorption of phenol on the adsorbent $(\mathrm{mg} / \mathrm{g}), \mathrm{C}_{\mathrm{e}}$ is the equilibrium concentration of solute in the initial solution $(\mathrm{mg} / \mathrm{L}) . \mathrm{q}_{\mathrm{m}}$ and $\mathrm{K}_{\mathrm{L}}$ represent the adsorption capacity of a monolayer and are related to the Langmuir adsorption equation constants. The Langmuir parameters are calculated using the slope of the line and the width of the origin from the equation of the line $\mathrm{C}_{\mathrm{e}}$ versus $\mathrm{C}_{\mathrm{e}} / \mathrm{q}_{\mathrm{e}}$ [24].

\section{RESULTS AND DISCUSSION}

Using SEM analysis, the size of the nZVI produced was approximately $55 \mathrm{~nm}$ Which is shown in Figure1. The nanoparticles produced are black, which indicates that they are zero-valent

\section{Effect of pH on the removal efficiency of phenol by adsorbents}

Figures 2 and 3 show the results related to the removal efficiency of adsorbents of nZVI and GnZVI against different $\mathrm{pHs}$ with the same other laboratory and measured parameters. Phenol has a higher removal efficiency in contact with adsorbents at acidic pHs, which

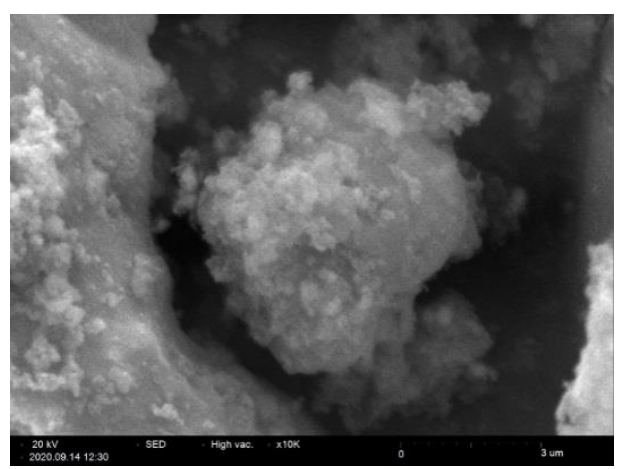

Figure 1. Scanning electron microscope of synthesized nZVI

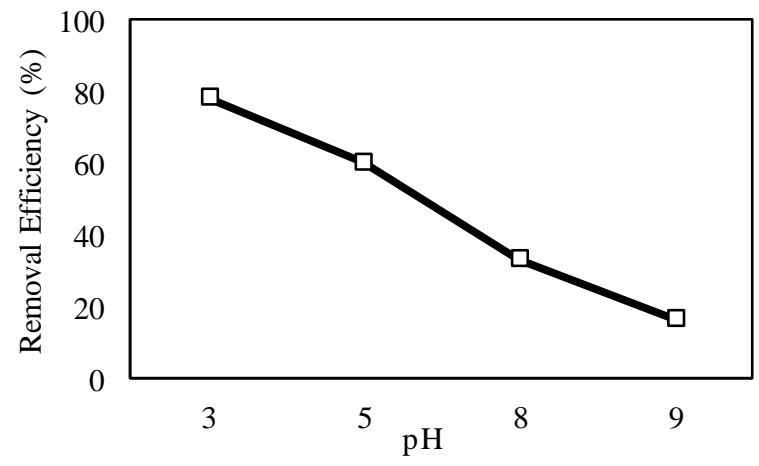

Figure 2. Removal of phenol at different solution $\mathrm{pH}$ (contact time: $60 \mathrm{~min}$, phenol concentration: $8 \mathrm{mg} / \mathrm{L}$, nZVI doses: $2.5 \mathrm{~g}$ ) 


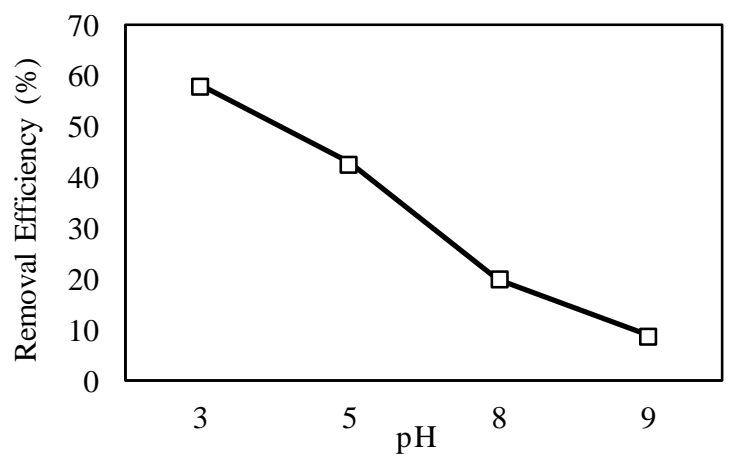

Figure 3. Removal of phenol at different solution $\mathrm{pH}$ (contact time:60 min, phenol concentration: $8 \mathrm{mg} / \mathrm{L}$, GnZVI doses: $2.5 \mathrm{~g}$ )

can be attributed to the lack of iron hydroxide formation in acidic environments, which means that adsorbent surfaces have a better ability to trap phenol. Phenol degradation efficiency was evaluated at the different $\mathrm{pHs}$ 3, 5, 8, 9. At pH 3 phenol 78.05 showed the highest removal rate and at $\mathrm{pH} 9,16.43 \%$ showed the lowest removal rate with nZVI, while GnZVI showed the highest removal rate at 58.19 and $9 \%$, respectively.

\section{Effect of contact time on the removal efficiency of phenol}

Contact time is one of the influential factors in deletion. The removal efficiencies of the two adsorbents at four contact times of 10, 20, 40, and 60 minutes are shown in Figures 4 and 5. As can be seen, in the early times, nZVI and granular adsorbents were capable of removing $41.7 \%$ and $27 \%$, respectively. However, with increasing contact time of adsorbents with phenol, the removal efficiency increases by almost $30 \%$ in 60 minutes for both adsorbents. The removal process improves over time due to more corrosion of the iron particle surface, creating cavities and increasing the surface area for adsorption.

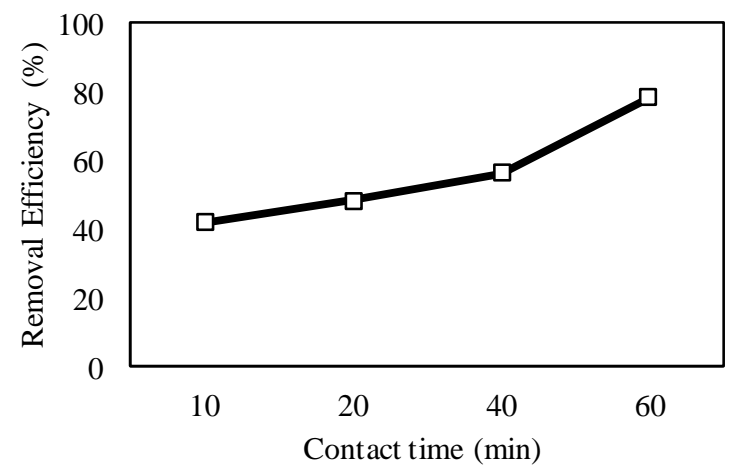

Figure 4. Removal efficiency of phenol at different times ( $\mathrm{pH}:$ 3, phenol concentration: $8 \mathrm{mg} / \mathrm{L}$, nZVI doses: $2.5 \mathrm{~g}$ )



Figure 5. Removal efficiency of phenol at different times (pH: 3, phenol concentration: $8 \mathrm{mg} / \mathrm{L}$, GnZVI doses: $2.5 \mathrm{~g}$ )

\section{Effect of adsorbent dosage on phenol removal efficiency}

The adsorbents used in this study were prepared in the amounts of 1, 1.5, 2, $2.5 \mathrm{~g}$. Figure 6 shows that the lowest amount of nZVI for phenol removal has an efficiency of $31.75 \%$ and with increasing the amount of adsorbent to $2.5 \mathrm{~g}$, the removal efficiency increases to $78.05 \%$. GnZVI in the lowest and highest adsorbent for phenol removal in Figure 7 shows the numbers 18.43 and 58\%, respectively. In fact, with increasing the amount of adsorbents, the efficiency of the phenolremoval process increases. this is due to the greater participation of particles in the process, followed by higher levels of adsorption.

\section{The effect of increasing phenol dosage on removal efficiency}

Figures 8 and 9 show the effect of increasing the phenol concentration from 8 to $32 \mathrm{ppm}$ for the two adsorbents. The finding indicates that an increase in phenol concentration decreased the adsorption capacity. nZVI and GnZVI at concentrations of $8 \mathrm{ppm}$ phenol show efficiencies of 78.05 and $57.83 \%$, respectively. These numbers indicate that at high concentrations, the active sites of adsorption are saturated with contaminant ions,

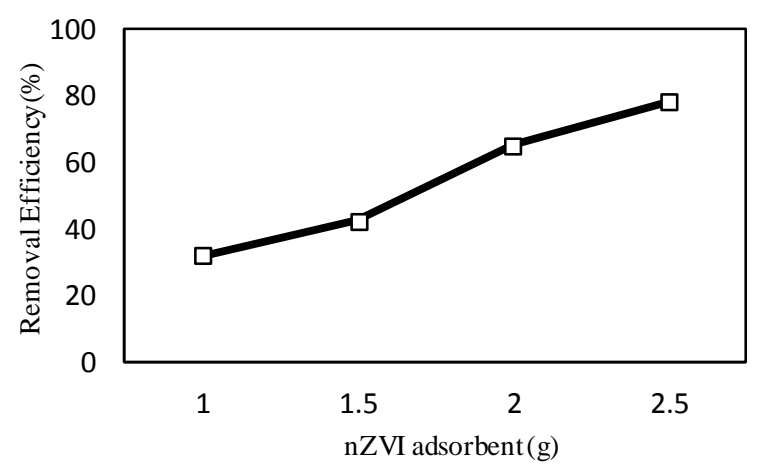

Figure 6. Removal of phenol by using different nZVI dosage (pH: 3, phenol concentration: 8 (mg/L), contact time: $60 \mathrm{~min})$ 


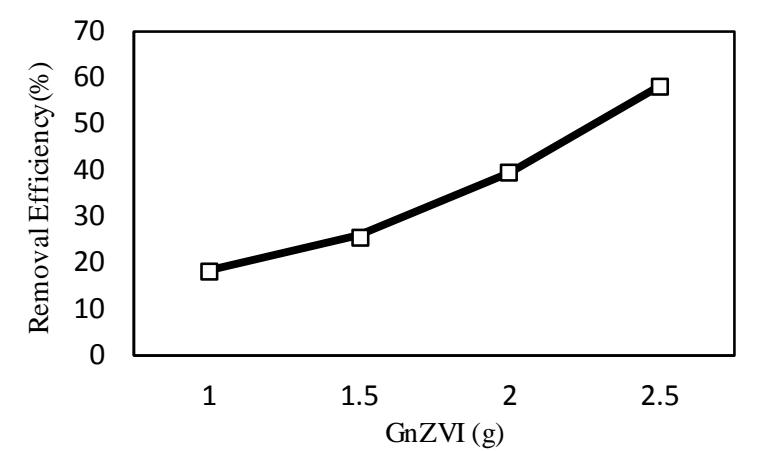

Figure 7. Removal of phenol by using different GnZVI dosage ( $\mathrm{pH}: 3$, phenol concentration: $8 \mathrm{mg} / \mathrm{L}$, contact time: $60 \mathrm{~min})$

which reduces the efficiency of the process. As can be seen at a concentration of $32 \mathrm{ppm}$, the removal efficiencies for nZVI and Gnzvi adsorbents are 26.18 and $7.85 \%$, respectively.

\section{Evaluation of adsorption isotherms}

Adsorption data were analyzed by two types of Freundlich and Langmuir isotherm models. The theoretical parameters of the models along with the regression coefficient are shown in Table 1. According to

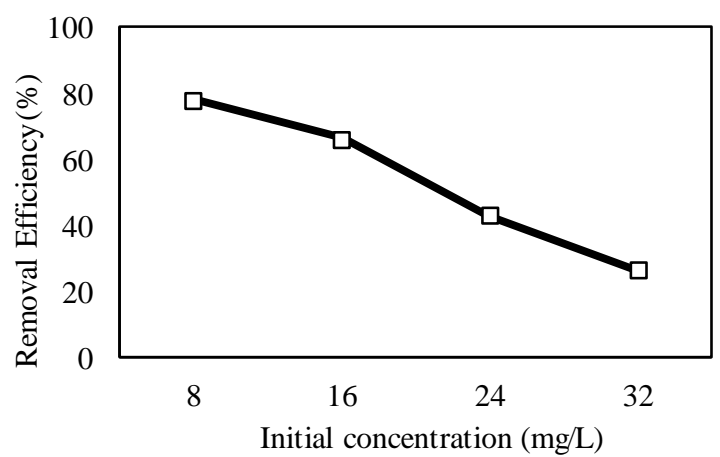

Figure 8. Removal of phenol at different initial phenol concentration (pH: 3, nZVI dose: $2.5 \mathrm{~g}$, contact time: $60 \mathrm{~min}$ )

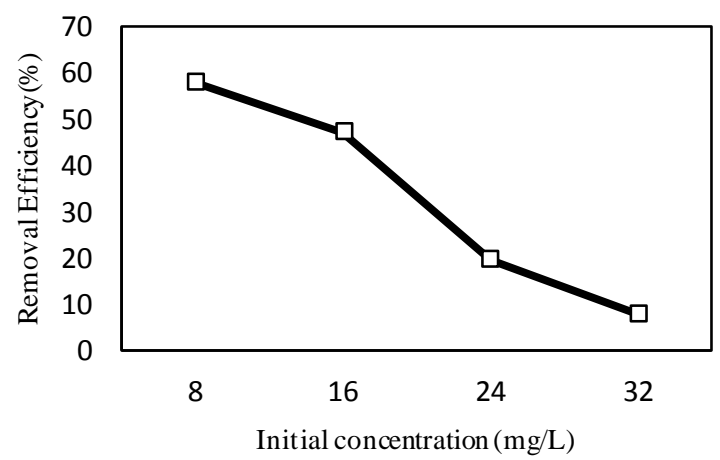

Figure 9. Removal of phenol at different initial phenol concentration (pH: 3, Gnzvi dose: 2.5 g, contact time: 60 $\min )$
Table 1. Parameters of the Freundlich and Langmuir isotherms

\begin{tabular}{lccccc}
\hline Model & $\mathbf{n}$ & $\mathbf{R}^{2}$ & $\mathbf{q} \mathbf{m}$ & $\mathbf{K}_{\mathbf{L}}$ & $\mathbf{K}_{\mathbf{f}}$ \\
\hline Freundlich & 0.75 & 0.92 & - & - & 61.4 \\
Langmuir & - & 0.88 & 45.7 & 0.11 & - \\
\hline
\end{tabular}

the $\mathrm{R}^{2}$ value of each model, it is determined that the Freundlich model has the highest value and is the best model in the adsorption of phenol by the studied nZVI adsorbent.

\section{CONCLUSION}

The results of this study show that the adsorption process with adsorbents produced from the waste is a good way to remove phenol. The removal efficiency depends on various factors such as $\mathrm{pH}$, contact time, adsorbent amount, and contaminant concentration. In this study, the highest removal efficiency was obtained at acidic $\mathrm{pH} 3$, contact time of 60 minutes, amount of $2.5 \mathrm{~g}$ of adsorbent, and concentration of $8 \mathrm{mg} / \mathrm{L}$ phenol. Under these conditions, the amount of phenol removal by nZVI and GnZVI was 78.05 and 58.19\%, respectively. The findings also show that the adsorption of phenol by nZVI in all experiments is more than GnZVI, which can be attributed to the increase in contact surface and high active sites for nZVI compared to GnZVI. Results from isothermal studies showed that the correlation coefficient of the Freundlich isotherm equation in the limit is relatively high. Therefore, it can be said that phenol removal follows the Freundlich is otherm equation.

\section{REFERENCES}

1. Kumaran, P., and Paruchuri, Y. L. 1997. "Kinetics of phenol biotransformation." Water Research, 31(1), pp.11-22. https://doi.org/10.1016/S0043-1354(99)80001-3

2. Daraei, H., Mittal, A., Noorisepehr, M., and Daraei, F. 2013. "Kinetic and equilibrium studies of adsorptive removal of phenol onto eggshell waste." Environmental Science and Pollution Research, 20(7), pp.4603-4611. https://doi.org/10.1007/s11356012-1409-8

3. Zazouli, M. A., and Taghavi, M. 2012. "Phenol Removal from Aqueous Solutions by Electrocoagulation Technology Using Iron Electrodes:Effect of Some Variables." Journal of Water Resource and Protection, 04(11), pp.980-983. https://doi.org/10.4236/jwarp.2012.411113

4. Bazrafshan, E., Biglari, H., and Mahvi, A. H. 2012. "Phenol removal by electrocoagulation process from aqueous solutions." Fresenius Environmental Bulletin, 21(2), pp.364-371. Retrieved from https://www.cabdirect.org/cabdirect/abstract/20123174578

5. Bevilaqua, J. V., Cammarota, M. C., Freire, D. M. G., and Sant'Anna Jr., G. L. 2002. "Phenol removal through combined biological and enzymatic treatments." Brazilian Journal of Chemical Engineering, 19(2), pp.151-158. https://doi.org/10.1590/S0104-66322002000200010 
6. Tziotzios, G., Teliou, M., Kaltsouni, V., Lyberatos, G., and Vayenas, D. V. 2005. "Biological phenol removal using suspended growth and packed bed reactors." Biochemical Engineering Journal, 26(1), https://doi.org/10.1016/j.bej.2005.06.006

7. Xu, J., Duan, W., Zhou, X., and Zhou, J. 2006. "Extraction of phenol in wastewater with annular centrifugal contactors." Joumal of Hazardous Materials, 131(1-3), pp.98-102. https://doi.org/10.1016/j.jhazmat.2005.09.011

8. Jiang, L., and Mao, X. 2012. "Degradation of Phenol-containing Wastewater Using an Improved Electro-Fenton Process" International Journal of Electrochemical Science, 7, pp.4078$4088 . \quad$ Retrieved from http://www.electrochemsci.org/papers/vol7/7054078.pdf

9. Hao, X., Pritzker, M., and Feng, X. 2009. "Use of pervaporation for the separation of phenol from dilute aqueous solutions." Joumal of Membrane Science, 335(1-2), pp.96-102. https://doi.org/10.1016/j.memsci.2009.02.036

10. Das, S., Banthia, A. K., and Adhikari, B. 2008. "Porous polyurethane urea membranes for pervaporation separation of phenol and chlorophenols from water." Chemical Engineering Journal, $138(1-3)$ https://doi.org/10.1016/j.cej.2007.06.030

pp.215-223.

11. Nicell, J. A., Saadi, K. W., and Buchanan, I. D. 1995. "Phenol polymerization and precipitation by horseradish peroxidase enzyme and an additive." Bioresource Technology, 54(1), pp.5-16. https://doi.org/10.1016/0960-8524(95)00104-2

12. Salame, I. I., and Bandosz, T. J. 2003. "Role of surface chemistry in adsorption of phenol on activated carbons." Journal of Colloid and Interface Science, 264(2), pp.307-312. https://doi.org/10.1016/S0021-9797(03)00420-X

13. Pajooheshfar, S. P., and Saeedi, M. 2009. "Adsorptive Removal of Phenol from Contaminated Water and Wastewater by Activated Carbon, Almond, and Walnut Shells Charcoal." Water Environment Research, 81(6), pp.641-648. https://doi.org/10.2175/106143008X390780

14. Nuria Fiol, T. B. 2013. "Adsorption on Activated Carbon from Olive Stones: Kinetics and Equilibrium of Phenol Removal from Aqueous Solution." Journal of Chemical Engineering \& Process Technology, 04(06). https://doi.org/10.4172/2157-7048.1000165

15. Heydaripour, J., Gazi, M., Oladipo, A. A., and Gulcan, H. O. 2019. "Porous magnetic resin-g-chitosan beads for adsorptive removal of phenolic compounds." International Journal of Biological Macromolecules, $123, \quad$ pp.1125-1131. https://doi.org/10.1016/j.ijbiomac.2018.11.168

16. Viraraghavan, T., and de Maria Alfaro, F. 1998. "Adsorption of phenol from wastewater by peat, fly ash and bentonite." Joumal of Hazardous Materials, 57(1-3), pp.59-70. https://doi.org/10.1016/S0304-3894(97)00062-9

17. Sarkar, M., and Acharya, P.K. 2006. "Use of fly ash for the removal of phenol and its analogues from contaminated water." Waste Management, 26(6), pp.559-570. https://doi.org/10.1016/j.wasman.2005.12.016

18. Devaanshi Jagwani, and Pranita Joshi. 2014. "Deportation of toxic phenol from aqueous system by wheat husk." International Joumal of Plant, Animal and Environmental Sciences, 4(2), pp.58-64. Retrieved from https://www.cabdirect.org/cabdirect/abstract/20143220265

19. Sahu, O., Rao, D. G., Gabbiye, N., Engidayehu, A., and Teshale, F. 2017. "Sorption of phenol from synthetic aqueous solution by activated saw dust: Optimizing parameters with response surface methodology." Biochemistry and Biophysics Reports, 12, pp.4653. https://doi.org/10.1016/j.bbrep.2017.08.007

20. Salehi, T., and Yousefi Kebria, D. 2020. "Synergy of Granular Activated Carbon and Anaerobic Mixed Culture in Phenol Bioremediation of Aqueous Solution." Iranian (Iranica) Joumal of Energy and Environment, 11(3), pp.178-185. https://doi.org/10.5829/IJEE.2020.11.03.01

21. Glavee, G. N., Klabunde, K. J., Sorensen, C. M., and Hadjipanayis, G. C. 1995. "Chemistry of Borohydride Reduction of Iron(II) and Iron(III) Ions in Aqueous and Nonaqueous Media. Formation of Nanoscale $\mathrm{Fe}, \mathrm{FeB}$, and $\mathrm{Fe} 2 \mathrm{~B}$ Powders." Inorganic Chemistry, 34(1), pp.28-35. https://doi.org/10.1021/ic00105a009

22. Yuvakkumar, R., Elango, V., Rajendran, V., and Kannan, N. 2011. "Preparation and characterization of zero valent Iron nanoparticles." Digest Journal of Nanomaterials and Biostructures, 6(4), pp.1771-1776. Retrieved from https://chalcogen.ro/1771_Yuvakkaur.pdf

23. Bai, X., Ye, Z.-F., Qu, Y.-Z., Li, Y.-F., and Wang, Z.-Y. 2009. "Immobilization of nanoscale $\mathrm{Fe} 0$ in and on PVA microspheres for nitrobenzene reduction." Journal of Hazardous Materials, 172(2 3), pp.1357-1364.https://doi.org/10.1016/j.jhazmat.2009.08.004

24. Shih, Y.-J., Chen, C.-W., Hsia, K.-F., and Dong, C.-D. 2015. "Granulation for extended-release of nanoscale zero-valent iron exemplified by hexavalent chromium reduction in aqueous solution." Separation and Purification Technology, 156, pp.10731081. https://doi.org/10.1016/j.seppur.2015.10.043

\section{COPYRIGHTS}

(C)2021 The author(s). This is an open access article distributed under the terms of the Creative Commons Attribution (CC BY 4.0), which permits unrestricted use, distribution, and reproduction in any medium, as long as the original authors and source are cited. No permission is required from the authors or the publishers. 
D. Yousefi Kebria and S. Mokhtarpour / Iranian (Iranica) Journal of Energy and Environment 12(2): 143-148, 2021

\section{Persian Abstract}

هيدروكربنهاى آروماتيك آلايندهاى سمى هستند كه از طريق صنايع مختلف وارد محيط مىشوند. اين آلايندها سرطانزا هستند و جهشهاى زنتيكى ايجاد

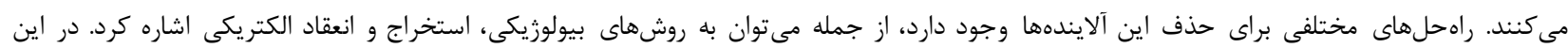

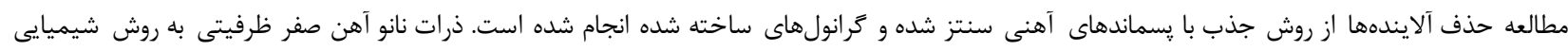
سنتز شده و با تركيب شدن با يلى وينيل الكل شكل گرانول نانوذرات آهن صفر ظرفيتى تشكيل مىشود. خصوصيات فيزيكى نانوذرات سنتز شده با استفاده از آناليز

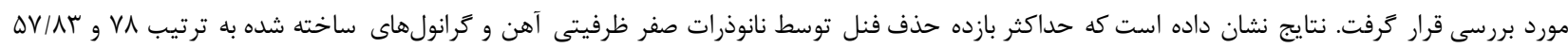

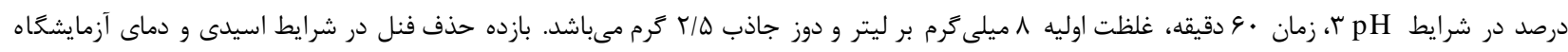

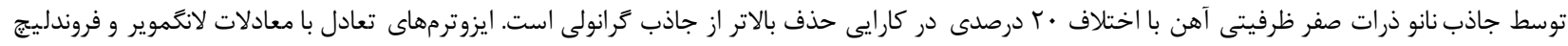

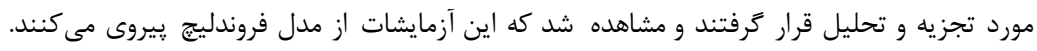

